\title{
Size and Shape: The Influence of Packaging on South African BOP Consumers' Decision-Making
}

\author{
Pravina Devpersadh Oodith \\ University of KwaZulu-Natal (Westville campus), South Africa \\ Oodithdp@ukzn.ac.za
}

\begin{abstract}
The bottom of the pyramid (BOP) proposition espouses the use of 'single-serve' or 'sachet' packaging in order to enhance affordability, encourage consumption and offer an assortment of good-quality products to BOP consumers. This study assesses the influence of packaging (in relation to size and price of different quantities) on South African BOP consumers' purchase decisions. The study analyses whether or not these consumers have a tendency to purchase smaller quantities of products as opposed to making bulk purchases. This study further investigates the impact that packaging criteria (storage, convenience of purchase, prices of different package sizes and reusability of packaging) have on consumers' decision-making. The aim is to uncover South African BOP consumers' perceptions of packaging as a decision-making influencer in order to formulate appropriate strategies that businesses can adopt in order to lucratively serve this market. Using area sampling, a sample of 600 BOP consumers living in relative poverty within the rural areas of South Africa was drawn. Data was collected using a self-developed questionnaire whose psychometric properties were statistically analyzed using descriptive and inferential statistics. The study's results reveal that although South African BOP consumers view small quantities of products as convenient and easy to store, the majority have an inclination to purchase large quantities instead of smaller package sizes. South African BOP consumers are also enticed to purchase products that are packaged in reusable containers, thereby, enabling the containers to be re-used after the consumption of the contents. Practical recommendations are articulated for business organizations.
\end{abstract}

Keywords: Bottom of the pyramid (BOP); single-serve packaging; sachet packaging; BOP consumer decisionmaking; reusable packaging; storage and convenience of packaging

\section{Introduction}

The eradication of poverty is at the forefront of many developing countries' economic and social goals, which has driven governments and non-governmental organizations (NGOs) to seek ways to uplift under privileged communities and promote human development. Prahalad (2005) proposes an unconventional alternative to global poverty alleviation, which affords the approximately 4 billion people who reside at the bottom of the economic pyramid (BOP) an opportunity to unburden themselves from the poverty trap and secure better lifestyles. The collaborative endeavors of government, NGOs, large domestic firms, multinational corporations (MNCs) as well as the poverty stricken citizens themselves can provide a propitious solution to global poverty reduction whilst simultaneously profiting business organizations that serve this multi-trillion-dollar market segment (Prahalad \& Hart, 2002). In order to successfully penetrate the BOP market, it is crucial for businesses to redesign their business strategies and direct their efforts at marketing good-quality yet lowcost products that will afford BOP consumers the opportunity to better satisfy their needs with their limited incomes, thereby, heightening their dignity and self-esteem (Prahalad, 2005). In order to accomplish this, MNCs need to enhance affordability of their products. Selling on credit to BOP consumers, obtaining microcredit from financial institutions, decreasing production costs and providing flexible payment schemes are some of the recommendations made to businesses in order to enhance affordability of their products (Anderson \& Billou, 2007; Pitta, Guesalaga \& Marshall, 2008; Prahalad, 2012).In addition, another innovation that delivers an array of products to BOP consumers and enhances affordability is the utilization of smaller packages and 'single-use' or 'sachet' packaging (Anderson \&Billou, 2007; Chatterjee, 2009; Prahalad, 2012). Prahalad (2012) asserts that smaller packages not only provides the poor with an assortment of products to choose from but also encourages consumption, as these smaller quantities are more affordable. This study evaluates the impact of packaging (in relation to size and price of different quantities) on South African BOP consumers' decision-making. The study also investigates the purchasing behavior of these consumers in relation to their preference for purchasing smaller packages as opposed to larger quantities of products. In addition, this study aims to provide insight into South African BOP consumers' perceptions of packaging as a decision-making influencer in order to articulate suitable strategies that can be implemented by business organizations to successfully serve this market. 
Purpose of the article: This article analyses whether or not South Africa BOP consumers have a propensity to purchase smaller quantities of products as opposed to making bulk purchases. In addition, this article will provide insight into the influence that packaging criteria (storage, convenience of purchase, prices of different package sizes and reusability of packaging) have on South African BOP consumers' decision-making.

\section{Literature Review}

An overview of the BOP market: The BOP proposition indicates that there is substantial untapped purchasing power at the bottom of the pyramid and that there is great potential for BOP markets to yield soaring profit margins for MNCs. Prahalad (2005) states that there are more than 4 billion people with a per capita income of less than $\$ 2$ per day, at purchasing power parity rates, and estimates that the BOP market size is enormous at $\$ 13$ trillion. These 4 billion or more people represent a prodigious majority of the population in developing countries of Asia, Africa, Eastern Europe, Latin America and the Caribbean with Asia, Africa and Latin America together, accounting for approximately $94 \%$ of the BOP population (World Economic Forum, 2009). The poorest segment of the BOP market resides in Africa (World Economic Forum, 2009). Although the World Economic Forum (2009) cites that the majority of the BOP consumers $(68 \%$ globally) dwell in rural areas, there are vast regional disparities within the global BOP market with regard to rural and urban concentration. For instance, in Africa and Asia, BOP markets are concentrated predominantly in rural areas whereas in Eastern Europe and Latin America there is a high concentration of BOP markets in urban areas (Dansk Industry International Business Development, 2007).

Prahalad (2005) believes that business organizations need to alter their perceptions of the poor in order to successfully penetrate BOP markets. Prahalad (2005) encourages organizations to view the poor as valueconscious consumers who encompass an ardent entrepreneurial drive that is conducive to co-creating propitious solutions that would alleviate poverty, improve consumers' well-being and garner profits for business organizations. By enlisting the help of impoverished individuals, businesses will not only provide employment opportunities to them but will also enhance their dignity and self-esteem. Prahalad and Hart (2002) outline that the key to profitably serving BOP markets is to place emphasis on ensuring large volumes of sales with low prices and profit margins. Simanis (2012), however, affirms that in order to reap profits through this 'low price, high volume' model, firms require an unrealistic penetration of more than $30 \%$ of consumers in the BOP target market. One of the dominant assumptions that Prahalad and Hart (2002) believe that MNCs make regarding BOP markets is that distribution access to this market is difficult and this serves as a paramount deterrent to servicing the needs of BOP consumers. Prahalad and Hart (2002) are confident that the problem of MNCs accessing the BOP market can be overcome through designing their distribution systems to cater for the needs of the rural consumers and by partnering with local people and village enterprises in order to improve distribution. Another misconception made by business organizations is that BOP consumers are not brand-conscious and will purchase the cheapest products on the market (Prahalad, 2005). Contrary to this, South African BOP consumers are brand-conscious and brands play an influential role in their purchase decisions (Oodith \& Parumasur, 2017). In addition, South African BOP consumers are highly loyal to their trusted brands, willing to pay premium prices for preferred brands and desire value-for-money from superior brands (Barki \& Parente, 2010; Majumder, 2012; Nakata \& Weidner, 2011; Neuwirth, 2012; Nyanga, 2015; Oodith \&Parumasur, 2017; Prahalad, 2012; Rijke, Diehl \& Schoormans, 2009; Subrahmanyan \& Gomez-Arias, 2008; Variawa, 2010).

Prahalad (2005) believes that by not servicing the needs of the poor, MNCs are disadvantaging these consumers because they are then subjected to the poverty penalty, which is paying a premium on purchases from local businesses in the BOP market as a result of not having alternative sources of supplies available to them. Mendoza (2008) defines the poverty penalty as the comparatively higher cost that is shouldered by the poor when participating in certain markets, in comparison to the non-poor. According to Mendoza (2008), the poverty penalty can assume at least five possible forms:

- Poor quality: products sold to the poor are of an inferior quality compared to those sold to non-poor consumers;

- Higher price: products sold to the poor are higher in price compared to similar goods that are sold to non-poor consumers; 
- Non-access: product prices are so exorbitant that the products become completely unaffordable to poor consumers;

- Non-usage: products are priced so excessively or are of such poor quality that poor consumers opt out of consumption and

- Catastrophic spending burden: the consumption of the product or service (e.g. healthcare) becomes such a necessity that the poor are faced with the arduous decision of how to finance the consumption thereof, as this will categorically result in curtailing spending on other necessities.

Prahalad (2005) argues that the poverty penalty can be eliminated if MNCs, with their large scale and scope of operations as well as management expertise, target BOP markets by offering these consumers a variety of products and services to choose from. In order to accomplish this, it is imperative for business organizations to develop a commercial infrastructure that will suit the dynamic needs of BOP consumers and overcome the challenges associated with servicing these markets (Prahalad\& Hart, 2002). Four crucial elements (creating buying power, shaping aspirations, improving access and tailoring local solutions) need to be taken into consideration in articulating this framework. Prahalad and Hart (2002) state that partnering with BOP consumers, providing employment opportunities to them, increasing their earnings potential, offering credit to them and improving accessibility of products are interventions that would enhance their buying power. In terms of shaping aspirations, Prahalad and Hart (2002) advise MNCs to use educational marketing communication messages that will not only assist BOP consumers in gaining an understanding of the operational functions of products but will also provide insight into how these products will enhance their health and well-being. In order to improve access, MNCs need to partner with BOP consumers and local businesses in order to harness existing infrastructure and communication links to distribute products to BOP markets (Prahalad\& Hart, 2002). In tailoring local solutions, careful consideration must be taken in terms of BOP consumers' purchasing habits, earnings, daily regimes and habitats (Prahalad\& Hart, 2002). In order to successfully penetrate BOP markets, MNCs need to modify their current business practices and marketing strategies so that they will be successful in targeting the approximately 4 billion people at the bottom of the economic pyramid. According to Prahalad (2012), one of the key success factors is to enhance affordability of products (through innovative, 'single-serve' or 'sachet' packaging) without compromising on quality.

The influence of packaging on BOP consumers' decision-making: Packaging is an element that assists in identifying a brand and comprises those activities involved in designing and producing a wrapper or container to house the product (Jobber \& Ellis-Chadwick, 2013). The basic functions of packaging are to protect the product, offer convenience to consumers in terms of easy transport and storage of products and to offer quantity variations to those consumers (particularly single-person households) wishing to purchase smaller quantities of products (Belch \& Belch, 2012; McDaniel, Lamb \& Hair, 2013; White, 2017). Dibb, Simkin, Pride and Ferrell (2012) add that another function of packaging is to promote the product's features, benefits, image and uses and that marketers often utilize reusable packaging to make the product more desirable by creating the perception of a ' 2 -in- 1 ' bargain deal in which consumers get a storage container to use after they have consumed the product. The important packaging considerations for marketers are to ensure that packaging is tamper-proof, child-proof, environmentally-friendly, recyclable and biodegradable (Dibb et al., 2012).

A vital role played by packaging is to build and maintain strong brand equity. Brand equity refers to the marketing and financial worth of the brand and a brand that has prominence in terms of awareness, loyalty and perceived quality usually encompasses superior brand equity (Dibb et al., 2012; McDaniel et al., 2013). The creation of a strong brand equity assists a brand in generating higher profit margins due to an increased sales volume, growing market share and ultimately adds to the company's competitive advantage (Schiffman \& Wisenblit, 2015). Packaging enables brand recognition through the use of various brand elements in the product packaging such as the brand names, logos, colors and visual structures (Keller, 2013). According to Keller (2013), packaging characteristics such as aesthetics and convenience, help create an emotional bond between the consumer and brand, thereby, increasing brand loyalty. In addition, Brakus, Schmitt and Zarantonello (2009 cited in Variawa, 2010) state that brand-related stimuli such as, brand colors, shapes, slogans, background design elements, mascots and brand characters assist BOP consumers with brand recognition and the establishment of intense brand associations. South African BOP consumers are remarkably astute in effortlessly differentiating between brands on the basis of the brands' logos, design 
and/or coloring and are able to easily identify the packaging of the products that they customarily purchase (Oodith \&Parumasur, 2017).

According to Keller (2013), packaging size and shape influences consumers' perceived value of a product as many consumers believe that the bigger the package, the better the value for their money. Keller (2013) further asserts that words and images on product packaging often influences consumers' perceived expectations of a product, which in turn affects their purchase decisions. Attractive designs, labels, and images are effective in influencing consumers' purchase decisions and allows organizations to differentiate their products from that of competitors' (White, 2017). Oodith and Parumasur (2017) found that, despite their low levels of education or illiteracy, South African BOP consumers are able to recognize brand names and packaging of products and use these as a means of identifying trusted brands. BOP consumers who have an inability to read often rely on visual cues (pictures on packaging) and brand logos as a safety mechanism for appraising the worth of brands (Dinica \& Motteau, 2012; Oodith \& Parumasur, 2017; Viswanathan, Rosa and Harris, 2005 cited in Nakata \& Weidner, 2011). Sehrawet and Kundu (2007) state that business organizations will be able to differentiate their offerings from a plethora of competing products in BOP markets through the effective selection of package shapes and features, brand colors, trademarks and logos.

The BOP proposition advocates the use of smaller-unit packages in order to encourage consumption, create affordability and offer a greater choice to BOP consumers. Dubey and Patel (2004) assert that smaller-unit packs or sachets tender a means of intensifying penetration of BOP markets, thereby, increasing volumes as well as creating opportunities for new and more frequent occasions for consumption. Prahalad and Hart (2002) and Dubey and Patel (2004) outlined that smaller packs or sachets of products like shampoos, makeup, snacks, beverages and confectionery have prompted BOP consumers to purchase these products. Further to this, Prahalad and Hart (2002) state that by utilizing single-serve packaging, BOP consumers are afforded the opportunity to switch brands every time they purchase. Dubey and Patel (2004) add that singleserve sachets encourage trial usage of brands, especially new introductions on the market, as BOP consumers do not commit a large amount of their limited financial resources to the purchase of bulk quantities.

According to Dubey and Patel (2004), using smaller package sizes boasts the benefits of:

- Increasing affordability for BOP consumers and attracting middle- and upper-income consumers to purchase these smaller package sizes under certain circumstances, such as for travelling purposes;

- Affording BOP consumers, the opportunity to consume branded products at a low cost;

- Encouraging trial purchases by BOP consumers;

- Providing greater variety in foods and beverages for a similar capital outlay;

- Enabling frequent purchases of products like ice creams, chocolates and cold drinks;

- Improving convenience in transportation, storage and use;

- Enabling companies to lower the cost of production in the long run and achieve economies of scale as small packs assist producers in increasing market size due to wider coverage and use.

The BOP consumers have an appreciation for reusable packaging in that it allows them to use the empty containers or bottles after the depletion of its contents. It is a common practice to reuse bottled water or energy drinks bottles for carrying drinking tap water and for the storage of other liquids. The BOP consumers also have a preference for creatively repackaged products that ensure smaller quantities as it increases the range of products that they are able to afford and store (Oodith \&Parumasur, 2013). Package quality influences non-BOP consumers' decisions to purchase products as these consumers often view packaging that is of a high quality to be associated with superior-quality products (White, 2017). Sehrawet and Kundu (2007) found that packaging also assists rural BOP consumers in their purchase decisions. The ease of storing the package is an important factor in influencing their purchasing behavior and these BOP consumers associate better packaging with a better-quality product. Other pertinent factors that influenced purchasing decisions were easy-to-carry package sizes, the weight of the packaging, simplicity, transparency and similarity of packaging (Dinica \& Motteau, 2012; Sehrawet \& Kundu, 2007).

Convenience and accessibility of products are important determinants of BOP consumers' purchasing behavior. A South African study on informal trade in townships revealed that spaza shops have become 
sensitive to the needs of local consumers and have revolutionized their offerings by repackaging consumer products into smaller quantities in order to enhance affordability and convenience, in that these consumers no longer have to walk distances of up to 10 kilometers to purchase cosmetics, spices and groceries (Terblanche, 2010 cited in Variawa, 2010). The study showed, for example, that entrepreneurs were selling sugar by the spoonful as opposed to $500 \mathrm{~g}$ packages which BOP consumers deemed to be too expensive (Terblanche, 2010 cited in Variawa, 2010). Hamilton (2003) found that although larger package sizes were within the household budget, there was still a preference by certain BOP households to make smaller purchases in order to avoid having too much of their income tied up in products that may not be consumed for some time.

Researchers (Goliath Business News, 2005; Jaiswal, 2007; Karnani, 2007) state that although small packages increase convenience and assists the poor in managing cash flows, it does not increase affordability. Further to this Karnani (2007) asserts that the only plausible way to increase affordability would be to reduce the price per use which he believes is not achievable by using sachet packaging. Byron (2007 cited in Davidson, 2009) states that single-serve packages may cost more than larger packages from a per-ounce basis which leads critics (Davidson, 2009; Jaiswal, 2007; Karnani, 2007) to believe that the poor are being misled into thinking that the smaller packages are cheaper whilst the true reality is that they are paying more on a per unit basis. Further to this, Karnani (2007) and Ireland (2008) point out that smaller unit packaging places additional burden on the environment with regard to pollution and that the higher costs associated with single-serve packaging ultimately erodes profits. Ireland (2008) agrees with Karnani (2007) that sachets and smaller package sizes are conducive to promoting impulse purchases by BOP consumers who, owing to lack of security and banking services, find it difficult to save money. However, Ireland (2008) asserts that the shopping occasion also has an influence on BOP consumer behavioral practices in relation to the package sizes that they purchase. Certain commodities that can be classified as planned purchases result in some BOP consumers opting to postpone their buying until they visit supermarkets where they are able to acquire the larger formats that are cheaper on a per unit basis than sachets (Ireland, 2008).

\section{Methodology}

Respondents: The study population comprised residents of rural areas within South Africa who are classified as people living in relative poverty. The researcher was able to determine the population of this study using a Desktop Research Report from the South African Institute of Race Relations that contained the 2012relative poverty statistics of 278 municipalities and districts in South Africa. The number of individuals living in relative poverty in each of the regions was calculated using the population sizes (per region) and the corresponding rates of poverty. The researcher identified the population for the study as those individuals residing in districts with a poverty rate of $70 \%$ or more but owing to the fact that there are provinces with a higher prevalence of poverty than others, the researcher further defined the population to include individuals from the top three municipalities with the highest poverty rates (above $70 \%$ ) per province resulting in a population of 2556422 elements. By utilizing an online Sample Size Calculator, a sample of 600 subjects was generated using the population of 2556422 constituents, a confidence level of $95 \%$ and a confidence interval of $4 \%$ (Sample Size Calculator, 2014).

This study utilized the area sampling approach. Through this sampling approach, the total population is separated into clusters of elements which can be arbitrarily chosen for the study (Blumberg, Cooper \& Schindler, 2008). Based on the area sampling design, homogeneous clusters of BOP consumers in South Africa have been identified according to the different municipalities within the various provinces in South Africa. Due to the lack of time and financial resources, the researcher decided to conduct fieldwork in the Eastern Cape, KwaZulu-Natal and Limpopo provinces as these provinces reported the highest number of people living in relative poverty. The rural areas within the chosen provinces comprised mainly Black South Africans and in a bid to obtain a varied perspective from the inclusion of another racial group in South Africa, the Western Cape, which houses predominantly Colored South Africans, was included in the sample.

Although the minimum sample for the study was 600 subjects, 631 correctly completed questionnaires were received by the researcher. The adequacy of the sample was further determined using the Kaiser-Meyer-Olkin Measure of Sampling Adequacy (0.816) and the Bartlett's Test of Spherecity (1472.092; $p=0.000$ ) for factors 
relating to packaging/quantity, which respectively indicated suitability and significance. The results indicate that the normality and homoscedasticity preconditions are satisfied. With regard to the composition of the sample, there were less male (41.5\%) than female (58.5\%) respondents. The Eastern Cape (36.6\%) and KwaZulu-Natal (36.5\%) provinces reported the highest percentage of respondents for this study. The Limpopo province comprised $22.2 \%$ of the respondents whilst $4.8 \%$ of the participants were from the Western Cape. There were only two race groups represented in the sample of this study. Black South Africans constituted $95.2 \%$ of the respondents whilst Colored South Africans accounted for the remaining $4.8 \%$ of the respondents. In terms of age, the 30-39 years (22.3\%) and 40-49 years (22.2\%) age group categories reported the highest percentage of respondents. The 18-29 years' age category had a $20.9 \%$ representation in terms of respondents, followed by the 50-59 years (17.6\%) and 60 years and over (17\%) age categories. Respondents with a high school educational background accounted for the majority (37.9\%) of the sample whilst $35 \%$ of the participants were in possession of a primary school educational qualification. Respondents who had no formal education at all comprised $15.2 \%$ of the sample. Respondents who acquired diploma qualifications comprised $9.4 \%$ of the sample and the minority $(2.5 \%)$ of the respondents were graduates with degree qualifications. In terms of income, $26.5 \%$ of the respondents earned between R1001 and R1500 per month, followed by the R251-R500 (20.9\%) and R501-R1000 (20.8\%) monthly income categories. Respondents with monthly earnings between R1501 and R2000 comprised $11.3 \%$ of the sample whilst $10.9 \%$ of the respondents earned above R2000 per month. Respondents with earnings below R250 per month comprised $9.7 \%$ of the sample for this study.

Measuring instrument, the research instrument for this study was a questionnaire. In formulating the questionnaire, the researcher ensured that a simple questionnaire that suited the level of understanding and level of education of the BOP respondents was designed. In order to facilitate easier understanding of the statements in the questionnaire, the questionnaire was translated by a reputable company into three African languages of preference (isi-Zulu, Tshivenda and Xhosa) - certified, for the various provinces. The enormity of this study (sample of 600 elements) and the predominantly low levels of education of the BOP respondents had warranted the use of closed-ended questions that were both positively and negatively worded. The questionnaire was categorized into two sections. Section A of the questionnaire used a nominal scale to record the biographical details (age, highest educational qualification, monthly income, number of people living in a household, gender and race) of the BOP consumers. Section B of the questionnaire used an ordinal scale in which consumers were requested to rank certain variables in order of importance to them, as well as an interval scale in the form of a 5-point Likert scale. Statements 35 to 41 in Section B of the questionnaire related to the packaging/quantity dimension of this study which was further categorized according to package size (5 items) and price (2 items). Prior to the actual commencement of this study, a pilot test was performed on a minute group of 15 BOP consumers from the KwaZulu-Natal province. The purpose of the pilot test was to examine the viability of the proposed procedure, as well as uncover potential inadequacies and defects in the measurement procedures. The appropriateness of the design of the questionnaire was also investigated and the results indicated that no changes were required before the actual commencement of this study.

Research procedure: The research was only undertaken after ethical clearance was obtained for the study and upon completion of the pilot study.

Measures/statistical analysis of questionnaire: The validity of the questionnaire was statistically assessed using Factor Analysis. When undertaking the Factor Analysis, only items with loadings greater than 0.4 were considered. Furthermore, when an item loaded significantly on two factors, only that with the highest value was considered. The packaging/quantity dimension of this study was sub-divided into two components, namely, package size and price of different quantities in order to investigate the impact that the prices of different quantities have on BOP consumers' buying behavior and the influence of packaging variables (storage, convenience of purchase, reusability of packaging) on decision-making. The item loadings determining the factors are outlined in Table 1. 
Table 1: Factor Analysis-Validity of the questionnaire assessing Packaging/Quantity

\begin{tabular}{lll}
\hline & Component \\
& $\mathbf{1}$ & $\mathbf{2}$ \\
\hline B35 & 0.863 & 0.044 \\
B36 & 0.886 & 0.017 \\
B37 & 0.813 & -0.065 \\
B38 & 0.276 & 0.702 \\
B39 & -0.005 & 0.422 \\
B40 & 0.831 & -0.007 \\
B41 & 0.383 & -0.709 \\
Eigenvalue & 3.104 & 1.180 \\
Percent of Total Variance & 44.34 & 16.85 \\
\hline
\end{tabular}

Table 1 indicates that 4 items load significantly on Factor 1 and account for $44.3 \%$ of the total variance. Three items relate to package size and 1 item relates to the price of different package quantities. Since the majority of items relate to package size, Factor 1 may be labelled likewise. Table 1 indicates that 3 items load significantly on Factor 2 and account for $16.9 \%$ of the total variance. Two items relate to package size and 1 item relates to the price of different package quantities. Since there is a higher significance in the item relating to price of different package quantities, Factor 2 will be labelled likewise.

Administration of measuring instrument: With the assistance of trained fieldworkers, data was collected through personally administered questionnaires. The justification for utilizing this approach was due to the fact that most South African BOP consumers residing in rural areas have low levels of education and literacy which necessitated the use of trained fieldworkers in order to correctly complete of the questionnaires. The researcher recruited and trained a team of fieldworkers from the selected provinces (Eastern Cape, Western Cape, Limpopo and KwaZulu-Natal) who ensured that there was an avoidance of a low-response rate and incomplete questionnaires.

Statistical analysis of data: Descriptive statistics (mean, variance, standard deviation) and inferential statistics (correlation, Kruskal-Wallis One-way ANOVA, Mann-Whitney U-Test, Kruskal-Wallis t-Test) were used to evaluate the objectives and hypotheses of the study.

\section{Results}

The results acquired relating to the 'packaging/quantity' dimension of the study will be presented using descriptive statistics (Table 2). The respondents of this study (BOP consumers) were asked to rate their perceptions of the 'packaging/quantity' dimension of the study using a $1-5$ point Likert scale.

Table 2: Descriptive Statistics: Packaging/Quantity Dimension of the Study

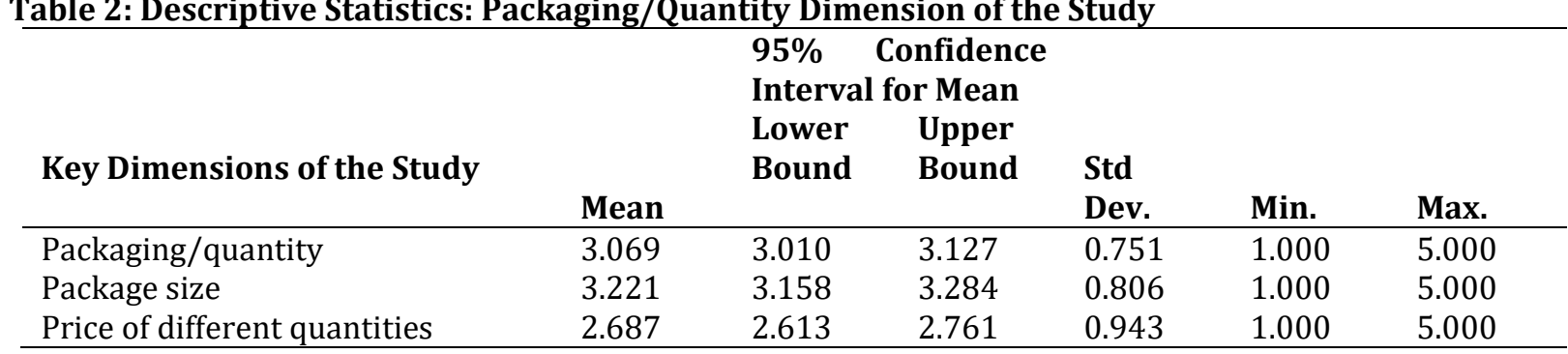

In terms of South African BOP consumers' perceptions of the key dimension of packaging/quantity (Table 2), the higher the mean score, the more positively the sub-dimension is viewed. Against a maximum attainable score of 5, it is evident from Table 2 that South African BOP consumers are very cognizant of package sizes and quantities when making their purchase decisions (Mean $=3.069)$. Their level of consciousness in relation to packaging/quantity (Mean $=3.069$ ) is a synthesis of their awareness of varied package sizes, price, 
assortment of products and convenience of purchasing and storing packages for which frequency analyses were undertaken.

In terms of quantity and package sizes, $35.3 \%$ of the BOP consumers agree that buying smaller packages of goods allows for better storage within households as these smaller packages require less storage space and $36.6 \%$ of the respondents admit to buying smaller packages as the prices are comparatively lower than larger packages. The results of the study also reveal that the majority of respondents $(69.7 \%)$ admit that they are enticed to purchase products that are packaged in containers in order to reuse these containers after their contents have been depleted. In terms of purchasing luxury beauty and hair-care products, $36.5 \%$ of BOP consumers agree and a further $7.9 \%$ strongly agree that they do engage in purchasing beauty and hair-care products for special occasions. The results of the study show that $37.1 \%$ of respondents agree and a further $13.5 \%$ strongly agree that buying smaller quantities of goods enables them to purchase an assortment of products with their meagre incomes. The results of the study reveal that $40.9 \%$ of the BOP consumers disagree and a further $23.6 \%$ strongly disagree that they refrain from purchasing large quantities of products in order to reap savings at a later stage.

As mentioned previously, the packaging/quantity dimension of this study was further categorized into two components, namely, package size and price of different quantities in order to ascertain whether or not price influences South African BOP consumers' decisions to purchase certain package sizes. In addition, the package size component enables the researcher to analyses the importance of certain criteria (storage, convenience of purchase, reusability of packaging) on the buying behavior of South African BOP consumers. Against a maximum attainable score of 5, it is apparent from Table 2 that South African BOP consumers are very mindful of these criteria (storage, convenience of purchase, reusability of packaging) when making their purchase decisions (Mean $=3.221$ ). However, as evidenced in Table 2, price has a mediocre influence on South African BOP consumers' decisions to purchase certain package sizes or quantities (Mean $=2.687$ ). In order to further probe the importance that BOP consumers attach to the components of the packaging/quantity dimension of the study, mean analyses were undertaken (Table 3).

Table 3: Descriptive Statistics: Packaging/Quantity Dimension of the Study

\begin{tabular}{|c|c|c|c|c|c|c|}
\hline \multirow{4}{*}{$\begin{array}{l}\text { Components of } \\
\text { Packaging/Quantity } \\
\text { Dimension of the Study }\end{array}$} & \multirow{3}{*}{ the } & \multicolumn{5}{|c|}{ 95\% Confidence } \\
\hline & & Lower & Upper & & & \\
\hline & & Bound & Bound & Std & & \\
\hline & Mean & & & Dev. & Min. & Max. \\
\hline Convenience & 3.014 & 2.910 & 3.119 & 1.340 & 1.000 & 5.000 \\
\hline Easy storage & 3.163 & 3.059 & 3.268 & 1.338 & 1.000 & 5.000 \\
\hline Lower Price & 2.998 & 2.903 & 3.094 & 1.221 & 1.000 & 5.000 \\
\hline Reusable packaging & 3.739 & 3.652 & 3.825 & 1.103 & 1.000 & 5.000 \\
\hline Luxury purchases & 3.010 & 2.914 & 3.105 & 1.218 & 1.000 & 5.000 \\
\hline Assortment of products & 3.181 & 3.084 & 3.277 & 1.238 & 1.000 & 5.000 \\
\hline Bulk purchases & 2.376 & 2.287 & 2.464 & 1.133 & 1.000 & 5.000 \\
\hline
\end{tabular}

Table 3 indicates that BOP consumers attach varying degrees of importance to the various packaging/quantity criteria that influence purchase decisions which, in descending level of mean score values, are: -

- $\quad$ Reusable packaging $($ Mean $=3.739)$

- $\quad$ Assortment of products (Mean = 3.181)

- $\quad$ Easy storage $(\mathrm{Mean}=3.163)$

- $\quad$ Convenience $($ Mean $=3.014)$

- $\quad$ Luxury purchases $($ Mean $=3.010)$

- $\quad$ Lower Price (Mean = 2.998)

- $\quad$ Bulk purchases $($ Mean $=2.376)$ 
As evident in Table 3, the most important packaging/quantity criteria used by BOP consumers in their purchase decisions is the ability to reuse the containers after the consumption of its contents (Mean $=3.739$ ). The ability to purchase an assortment of products that were packaged in smaller quantities (Mean $=3.181$ ) with limited income and the ease of storage of these smaller quantities in households (Mean $=3.163$ ) are also of paramount importance to BOP consumers when making their purchase decisions. According to the results of the study (Table 3), the purchase of bulk packages in order to reap savings later on (Mean $=2.376$ ) has the least level of importance to these consumers when making purchase decisions. When engaging in purchase decision-making, BOP consumers consider a multitude of factors and evaluative criteria (branding, savings potential/ability to pay off debt, price/affordability, quality, appearance/acceptability, adaptability of existing products, functionality/performance, advertising/awareness, accessibility/availability and partnering with MNCs) that shape their buying behavior this study, the researcher analyses the influence of packaging/quantity in tandem with these variables on South African BOP consumers' purchase behavior. Two hypotheses were tested with regard to the quantity and package size dimension of the study.

Hypothesis 1: There exists significant intercorrelations amongst packaging/quantity and the other key dimensions (branding, savings potential/ability to pay off debt, price/affordability, quality, appearance/acceptability, adaptability of existing products, functionality/performance, advertising/awareness, accessibility/availability and partnering with MNCs) of the study relating to BOP consumers (Table 4).

Table 4: Correlation-Packaging/Quantity and Other Key Dimensions of the Study

\begin{tabular}{lll}
\hline Key Dimensions of the Study & r / p & Packaging/Quantity \\
\hline Packaging/quantity & r & 1.000 \\
Branding & $\mathbf{p}$ & \\
& $\mathrm{r}$ & 0.004 \\
Savings potential/ability to pay off debt & $\mathbf{p}$ & $\mathbf{0 . 9 2 5}$ \\
& $\mathbf{p}$ & 0.013 \\
Price/affordability & $\mathrm{r}$ & $\mathbf{0 . 7 4 7}$ \\
& $\mathbf{p}$ & 0.396 \\
Quality & $\mathrm{r}$ & $\mathbf{0 . 0 0 0}$ \\
& $\mathbf{p}$ & -0.270 \\
Appearance/acceptability & $\mathrm{r}$ & $\mathbf{0 . 0 0 0}$ \\
& $\mathbf{p}$ & 0.018 \\
Adaptability of existing products & $\mathrm{r}$ & $\mathbf{0 . 6 4 8}$ \\
& $\mathbf{p}$ & 0.158 \\
Functionality/performance & $\mathrm{r}$ & $\mathbf{0 . 0 0 0}$ \\
& $\mathbf{p}$ & -0.335 \\
Advertising/awareness & $\mathrm{r}$ & $\mathbf{0 . 0 0 0}$ \\
& $\mathbf{p}$ & 0.161 \\
Accessibility/availability & $\mathrm{r}$ & $\mathbf{0 . 0 0 0}$ \\
Partnering with MNCs & $\mathbf{p}$ & -0.172 \\
& $\mathrm{r}$ & $\mathbf{0 . 0 0 0}$ \\
\hline
\end{tabular}

${ }^{*} \mathrm{p}<0.01,{ }^{* *} \mathrm{p}<0.05$

Table 4 indicates that there is a significant relationship between packaging/quantity and price/affordability, adaptability of existing products, advertising/awareness and partnering with MNCs and, a significant but inverse relationship between packaging/quantity and quality, functionality/performance and accessibility/availability, respectively, at the $1 \%$ level of significance. The implications of the significant relationships are that BOP consumers who are mindful of package sizes and quantities are price sensitive, prone to purchasing multi-purpose products that are designed for their living conditions, more inclined to buy products that are recommended by family and friends and are enthusiastic about partnering with MNCs. The significant, inverse relationships infer that BOP consumers who are more prone to purchasing smaller quantities of products tend to compromise on the quality of the products that they purchase and are less 
conscious of the products' performance and durability. Further to this, consumers who prefer to purchase smaller quantities are dissatisfied by the lack of assortment of products at their disposal and are more displeased by the long distances that they need to travel in order to acquire products from a supermarket. Therefore, Hypothesis 1 may be partially accepted.

Hypothesis 2: There is a significant difference in the perceptions of BOP consumers, varying in biographical profiles (age, highest educational qualification, monthly income and number of people living in a household, gender and race) regarding packaging/quantity (Table 5 and Table 6).

Table 5: Kruskal-Wallis One-way ANOVA/Mann-Whitney U-Test/Kruskal-Wallis t-Test: Biographical Variables and Packaging/Quantity

\begin{tabular}{|c|c|c|c|c|}
\hline & $\begin{array}{l}\text { Kruskal-Wallis One-way } \\
\text { ANOVA/ Kruskal - Wallis } \\
\text { T-Test } \\
\text { Chi-Square }\end{array}$ & & & \\
\hline Biographical Variables & & $\begin{array}{l}\text { Mann- } \\
\text { Whitney U }\end{array}$ & $\mathbf{Z}$ & $\mathbf{P}$ \\
\hline Age & 17.527 & & & $0.002^{*}$ \\
\hline Highest Educational Qualification & 15.363 & & & $0.004^{*}$ \\
\hline $\begin{array}{l}\text { Monthly Income } \\
\text { Number of People Living in a }\end{array}$ & 36.010 & & & $0.000^{*}$ \\
\hline Household & 7.919 & & & $0.048^{* *}$ \\
\hline Race & 0.491 & & & 0.484 \\
\hline Gender & & 41993.500 & -2.817 & $0.005^{*}$ \\
\hline
\end{tabular}

Table 5 indicates that there is a significant difference in the perceptions of BOP consumers varying in age, highest educational qualification, monthly income and gender regarding packaging/quantity at the $1 \%$ level of significance. Further to this and as evidenced in Table 5, there is a significant difference in the perceptions of BOP consumers varying in number of people living in a household regarding packaging/quantity at the 5\% level of significance. According to Table 5, no other significant differences exist. In order to assess where the significant differences lie, mean analyses were undertaken (Table 6).

Table 6 indicates that:

- BOP consumers, in the 60 years and over age category, do not view purchase decisions, based on quantity and package sizes, as favorably as consumers from the other age categories. The BOP consumers in this category are less likely to buy luxury beauty and hair-care products to be used for special occasions, or to purchase products in small quantities in order to obtain a large assortment of products from their incomes. The BOP consumers in this category are more prone to purchasing products in large quantities in order to reap future savings.

- The BOP consumers who are in possession of degrees, view purchase decisions, based on quality and package sizes, more favorably than the consumers from the other educational qualification categories. These individuals are more prone to buying small quantities of products because it facilitates easier transportation and storage at home. These consumers are also more likely to purchase products with reusable packaging and spend a higher proportion of their income on beauty and hair-care products.

- The BOP consumers with a monthly income above R2000 per month do not view purchase decisions, based on quantity and package sizes, as favorably as the BOP consumers from the other monthly income categories. The individuals in this category are more likely to purchase large quantities of products in order to reap future savings and are less likely to purchase small quantities of products simply because of the ease in transporting and storing them. The BOP consumers in this category are also less prone to purchasing small quantities of products for the sake of obtaining a wide assortment 
of products with their current incomes, which is comparatively more than the incomes of the BOP consumers from the other monthly income categories.

- The BOP consumers, residing in households consisting of 1-3 people, do not view purchase decisions, based on package sizes and quantity, as favorably as the BOP consumers from the other householdsize categories. Comparatively, these individuals are more likely to purchase large quantities of products in order to reap the benefits of future savings than the BOP consumers from the other household-size categories.

- Male BOP consumers have a greater preference for products in reusable packaging and in varying quantities and package sizes than female BOP consumers.

Table 6: Mean Analyses-Biographical Variables and Packaging/Quantity

\begin{tabular}{|c|c|c|c|c|c|}
\hline \multicolumn{3}{|c|}{ Biographical Variables } & Mean & Std Dev. & $\mathbf{N}$ \\
\hline \multirow{6}{*}{\multicolumn{2}{|c|}{ Age Categories (in years) }} & $18-29$ & 3.122 & 0.742 & 132 \\
\hline & & $30-39$ & 3.101 & 0.735 & 141 \\
\hline & & $40-49$ & 3.088 & 0.707 & 140 \\
\hline & & $50-59$ & 3.198 & 0.753 & 111 \\
\hline & & 60 and over & 2.800 & 0.786 & 107 \\
\hline & & Total & 3.069 & 0.751 & 631 \\
\hline \multicolumn{6}{|c|}{ Highest $\quad$ Educational } \\
\hline \multirow{6}{*}{\multicolumn{2}{|c|}{ Qualification }} & No education & 3.129 & 0.567 & 96 \\
\hline & & Primary school & 2.974 & 0.772 & 221 \\
\hline & & High school & 3.166 & 0.737 & 239 \\
\hline & & Diploma & 2.850 & 0.823 & 59 \\
\hline & & Degree & 3.366 & 1.041 & 16 \\
\hline & & Total & 3.069 & 0.751 & 631 \\
\hline \multirow{7}{*}{\multicolumn{2}{|c|}{ Monthly Income }} & Under R250 & 3.347 & 0.573 & 61 \\
\hline & & R251-R500 & 3.194 & 0.670 & 132 \\
\hline & & R501-R1000 & 3.177 & 0.736 & 131 \\
\hline & & R1001-R1500 & 2.867 & 0.806 & 167 \\
\hline & & R1501-R2000 & 3.153 & 0.665 & 71 \\
\hline & & Above R2000 & 2.781 & 0.827 & 69 \\
\hline & & Total & 3.069 & 0.751 & 631 \\
\hline \multicolumn{6}{|c|}{ Number of People Living in a } \\
\hline \multirow{5}{*}{\multicolumn{2}{|c|}{ Household }} & $1-3$ & 2.949 & 0.741 & 184 \\
\hline & & $4-6$ & 3.083 & 0.784 & 236 \\
\hline & & $7-9$ & 3.178 & 0.732 & 153 \\
\hline & & 10 or more & 3.101 & 0.654 & 58 \\
\hline & & Total & 3.069 & 0.751 & 631 \\
\hline \multirow{3}{*}{\multicolumn{2}{|c|}{ Gender }} & Male & 3.169 & 0.669 & 262 \\
\hline & & Female & 2.997 & 0.797 & 369 \\
\hline & & Total & 3.069 & 0.751 & 631 \\
\hline
\end{tabular}

From the results reflected in Table 5, it is evident that Hypothesis 2 may be partially accepted.

Discussion of results: In terms of quantity and package sizes, the outcomes of this study indicate that a moderate proportion of South African BOP consumers are of the opinion that purchasing smaller packages of goods is convenient, in that, these smaller packages require less storage space in households. The results of this study also reveal that approximately a third of South African BOP consumers opt for buying smaller packages as the unit prices are relatively lower than larger packages. The findings of this study, thereby, reveal that purchasing small quantities of products is not preferred by the majority of South African BOP consumers. This outcome is strongly corroborated by the findings of Variawa (2010) that South African BOP consumers prefer buying products in bulk. The results of this study also authenticates the findings of Ireland (2008) that BOP consumers in Venezuela refrain from purchasing smaller quantities and wait until they visit supermarkets in order to purchase larger formats of products that result in future savings. Furthermore, the current study's findings are consistent with the findings of AMPS SA (2008 cited in Variawa, 2010) that BOP 
consumers prefer buying in bulk as opposed to small sachets. In addition, a study by AC Nielsen (undated cited in Jaiswal, 2007) revealed that, for several products, the best-selling package size is the same across both BOP and non-BOP markets and that smaller package sizes are not the most popular quantities amongst BOP consumers. Dinica and Motteau (2012) support the viewpoint of Chikweche and Fletcher (2012) that due to the high uncertainty of delivery and forecasted product shortages, BOP consumers are inclined to purchase available products, in large or small quantities.

The outcomes of this study, however, contradict the findings of other studies wherein, BOP consumers have a preference for the purchase of sachets and smaller packages of goods which are inexpensive, increase penetration into BOP markets, create value for the poor, encourage impulse purchases and are suitable for less-essential 'luxury' products that are purchased for occasional usage (Anderson \& Markides, 2006; Chatterjee, 2009; Dansk Industri International Business Development, 2007; Dubey \& Patel, 2004; Hamilton, 2003; Ireland, 2008; Jaiswal, 2008; Karnani, 2007; Nakata \& Weidner, 2011; Sehrawet \& Kundu, 2007). Dubey and Patel (2004), Gordon (2008 cited in Louw, 2008), Pfeiffer and Massen, (2010) and Prahalad (2005) concur that sachets bring high-priced, branded products within BOP consumers' reach whilst still maintaining the perception that a high price is synonymous with superior quality. Sachets and smaller package sizes are conducive to encouraging brand sampling and minimizing the risks involved in trial usage of products (Dubey \& Patel, 2004; Jaiswal, 2008; Karnani, 2007). Due to limited incomes, BOP consumers deem it sensible to purchase smaller quantities of products in order to avoid having too much of their limited incomes tied up in larger package sizes that may not be consumed for some time (Chikweche\& Fletcher, 2010; Hamilton, 2003; Jaiswal, 2008; Kirchgeorg \& Winn, 2006). Hamilton (2003), Pfeiffer and Massen (2010), Pitta et al. (2008) and Prahalad (2005) add that the vast majority of BOP consumers, who do not possess stable cash flows that allow for pantry-loading, are inclined to purchase food products shortly before preparation and make smaller daily purchases. Limited storage space and an insecure environment at home create a greater propensity to purchase smaller quantities of products in order to promote the ease of storing goods within BOP households (Alsop \& Abrams, 1986 cited in Sehrawet \& Kundu, 2007; Dubey \& Patel, 2004; Mendoza, 2008; Rajagopal, 2009). Alsop and Abrams (1986 cited in Sehrawet \& Kundu, 2007) add that an important packaging characteristic that BOP consumers rely upon when selecting brands is the ease of storage of the product. Further to this, Sehrawet and Kundu (2007) found that easy transportation of packages is also of crucial importance to BOP consumers. Although single-serve packages increase convenience and allow the poor to better regulate their cash flows, it does not increase the real affordability of products and has a detrimental effect on the environment in the form of pollution (Chatterjee, 2009; Karnani, 2007; Kirchgeorg \& Winn, 2006). Davidson (2009) adds that BOP consumers are misled into thinking that single-serve sachets are cheaper when they are in fact paying much more on a per-unit basis.

As per the findings of this study, a moderate proportion of the South African BOP consumers are accustomed to purchasing smaller quantities of goods in order to acquire an assortment of products with their scarce incomes. This outcome is supported by Dubey and Patel (2004) and Kunreuther (1973 cited in Mendoza, 2008) who assert that sachets and smaller quantities provide BOP consumers with more variety of products with limited financial resources. According to the outcomes of this study, the majority of the South African BOP consumers are inclined to purchase products that are packaged in containers in order to reuse these containers once its contents have been consumed. This finding is consistent with the discoveries of Timol (2010 cited in Variawa, 2010), Tripathi and De (2007) and Variawa (2010) that reusable packaging provides value-for-money even after the consumption of the products. The current study's results indicate that there are significant relationships between packaging/quantity and the other key dimensions of this study.

Intercorrelations between packaging/quantity and other key dimensions of the study: In terms of the findings of this study, there is a significant relationship between packaging/quantity and advertising/awareness and partnering with MNCs and, a significant but inverse relationship between packaging/quantity and accessibility/availability, respectively. The significant relationships infer that BOP consumers who purchase larger quantities of products place greater emphasis on discounts and other promotional incentives and are highly prone to engage in partnerships with MNCs. The implication of the significant, inverse relationship is that BOP consumers who are more cognizant of the quantity and package sizes of products are displeased by the limited array of products at their disposal and are highly disgruntled 
by the long distances that they need to travel in order to purchase products from a supermarket. There were no other significant relationships between packaging/quantity and the key dimensions of this study.

Influences of biographical variables on packaging/quantity: According to the findings of this study, the South African BOP consumers' perceptions of the packaging and quantity of products are influenced by the biographical variables of age, education, monthly income, household-size and gender. Younger BOP consumers are more prone to purchasing luxury beauty and hair-care products and smaller quantities of commodities than older consumers. BOP consumers with lesser incomes tend to purchase smaller quantities of products, whereas, those in the higher income categories are inclined to purchase larger quantities of goods in order to reap the benefits of future savings. South African BOP consumers who earn lower incomes and who belong to larger households are more disposed to purchasing smaller quantities of products in a bid to secure a wide assortment of products with their measly incomes. The findings of this study illustrate that male BOP consumers prefer products in larger package sizes in comparison to female consumers.

Recommendations: Based on this study's results relating to the South African BOP consumers' perceptions of quantity and package sizes of products, the subsequent recommendations to business organizations are offered:

- Utilize sachet packaging for 'luxuries' like hair-care and cosmetic products when targeting young female South African BOP consumers: This strategy allows for easy transportation and enhances affordability of products that are purchased for occasional usage. In order to leverage scale effects for these companies, they could opt for increasing their market base for single-serve sachets by selling them for promotional purposes to retailers serving the non-BOP market as well as hotels, hospitals and airlines who require smaller quantities of consumer products. It is imperative for businesses to utilize biodegradable and environmentally-friendly sachet packages when pursuing this strategy. Single-serve sachet packaging is suitable when the target market for a product comprises South African BOP consumers who predominantly earn very low incomes and who belong to larger-sized households (Oodith \&Parumasur, 2014).

- Single-serve sachet packaging is useful for promotional purposes (free samples) that encourage brand trial: Owing to the fact that South African BOP consumers are highly skeptical about trusting new and unfamiliar brands, this approach will be ideal in allowing for trial usage of the free samples in order for the BOP consumers to ascertain, for themselves, the level of product quality.

- Provide incentive schemes for recycling: A workable strategy that encourages BOP consumers to recycle would be to offer a free product to those who collect a specified amount of used containers or packages and return them to the company. Depending on the nature and design of the packaging it can either be re-used or recycled by the company. Cash-back schemes would also provide additional income to BOP consumers for recycling used packages (Oodith \&Parumasur, 2014).

- Create ecologically sustainable packaging: This strategy will require MNCs to use biodegradable and recyclable materials in their packaging in order to reduce pollution. These innovations can be transferred to the developed markets for a global decrease in resource use and pollution (Oodith \&Parumasur, 2014).

- Wherever possible, utilize reusable containers for packaging products: South African BOP consumers are prone to purchasing products in reusable packaging as they are able to derive value-for-money from reusing the packaging after its contents have been depleted.

- Use a product-bundling approach to offer an assortment of affordable products of the same company: The results of this study reveal that a moderate proportion of the South African BOP population are enticed to purchase smaller quantities in order to obtain an array of different products with their limited incomes. This strategy will enable MNCs that specialize in different product categories to offer a product bundle whose overall price is lower than the sum of the individual product prices. This will enable MNCs to build brand loyalty and earn a reputation as an organization that provides a variety of good-quality products at reasonable prices.

- Offer quantity discounts on bulk purchases of consumer products: The results of this study indicate that the majority of South African BOP consumers prefer buying products in bulk in order to reap the benefits of future savings, as opposed to smaller quantities. Offering discounts on bulk purchases will render purchases more economical for South African BOP consumers. 
- Differentiate the brand's packaging through the use of highly distinct brand-related stimuli (such as, logos, package shapes and features, images, brand colors): South African BOP consumers are highly proficient in distinguishing between competing brands based on brands' logos, design and/or coloring. Therefore, MNCs need to ensure that the use of brand-related stimuli (such as, brand colors, shapes, slogans, background design elements, mascots and brand characters) is distinct enough to aid brand identification and the promotion of robust brand associations (Oodith \& Parumasur, 2017).

Future Research: A probe into BOP consumers' perceptions of packaging/quantity from a provincial perspective will be beneficial in order to uncover any equivalences and discrepancies in terms of packaging criteria (storage, convenience of purchase, reusability of packaging). Furthermore, data could be collected from the provinces (Free State, Gauteng, Mpumalanga, North West and Northern Cape) that were not included in this study, when comparing and contrasting South African BOP consumers' perception of packaging/quantity.

\section{Conclusion}

The results of this study, in relation to packaging/quantity, reveal that the majority of South African BOP consumers have a preference for purchasing products in bulk as opposed to smaller package sizes or sachets. Purchasing in bulk is deemed beneficial in terms of future savings, reducing the frequency of purchase occasions and the costs associated with transportation to and from supermarkets. South African BOP consumers are enticed to purchase products that are packaged in reusable containers or packaging, thereby, enabling the containers to be re-used after the consumption of the contents.

\section{References}

Anderson, J. \& Billou, N. (2007). Serving the World's Poor: Innovation at the Base of the Economic Pyramid. Journal of Business Strategy, [Online]. 28(2), 14-21. Accessed January 13, 2010, from the World Wide Web:http://www.emeraldinsight.com/Insight/ViewContentServlet? Filename $=/$ published/emeraldfulltextarticle/pdf/2880280204.pdf

Anderson, J. \& Markides, C. (2006). Strategic Innovation at the Base of the Economic Pyramid. Online. Accessed February 27, 2012, from the World Wide Web: http://www.jamieandersononline.com/uploads/ANDERSON_MARKIDES_SI_at_Base_of_Economic_Py ramid_FINAL.pdf

Barki, E. \& Parente, J. (2010). Consumer Behavior of the Base of the Pyramid Market in Brazil. Online. Accessed June 13, 2015, from the World Wide Web: http://embaconsortium.org/wpcontent/uploads/2013/09/Consumer-Behaviour-of-th e-BOP-Market-in-Br.pdf

Belch, G. E. \& Belch, M. A. (2012). Advertising and Promotion: An Integrated Marketing Communications Perspective (9 $9^{\text {th }}$ d), New York: McGraw-Hill.

Blumberg, B., Cooper, D. R. \& Schindler, P. S. (2008). Business Research Methods (2nd European ed), London: McGraw-Hill Higher Education.

Chatterjee, S. M. (2009). Multinational Firm Strategy and Global Poverty Alleviation: Frameworks and Possibilities for Building Shared Commitment. Journal of Human Values, [Online]. 15(2), 133-152. Accessed May 18, 2012, from the World Wide Web: http://jhv.sagepub.com/content/15/2/133

Chikweche, T. \& Fletcher, R. (2012). Understanding factors that influence purchases in subsistence markets. Journal of Business Research, [Online]. 63, 643-650. Accessed June 13, 2015, from the World Wide Web: http://www.sciencedirect.com/science/ article/pii/S0148296309001635

Dansk Industri International Business Development. (2007). Working with the Bottom of the Pyramid: Success in Low-income Markets. Online. Accessed February 27, 2012, from the World Wide Web: http://di.dk/SiteCollectionDocuments/DIBD/Working\%20with\%20the\%20Bottom\%20of\%20the\% 20Pyramid.pdf

Davidson, K. (2009). Ethical concerns at the bottom of the pyramid: Where CSR meets BOP. Journal of International Business Ethics, 2(1), 22-32.

Dibb, S., Simkin, L., Pride, W. M. \& Ferrell, O.C. (2012). Marketing: Concepts and Strategies (6 ${ }^{\text {thed), China: }}$ Cengage Learning. 
Dinica, I. \& Motteau, M. (2012). The market of the bottom of the pyramid: Impact on the marketing-mix of companies. Master's Thesis. Umea School of Business, Umea Univeritet.

Dubey, J. \& Patel, R. P. (2004). Small wonders of the Indian market. Online. Accessed January 22, 2012, from the World Wide Web: http://onlinelibrary.wiley.com/doi/ 10.1002/cb.165/pdf

Goliath Business News. (2005). Misfortune at the bottom of the pyramid. Greener Management International, [Online]. Accessed January 15, 2011, from the World Wide Web: http://goliath.ecnet.com/coms2/gi_0199-6693108/Misfortune-at-the-bottom-of.html

Hamilton, B. A. (2003). Creating Value for Emerging Consumers in Retailing. Online. Accessed February 27, 2012, from the World Wide Web: https://www.msu.edu/ course/aec/841/CoCa_Cola_Retailing\% 20in\%20SA_Executive\%2520Summary.pdf

Ireland, J. (2008). Lessons for successful BOP marketing from Caracas' slums. Journal of Consumer Marketing, [Online]. 25(7), 430-438. Accessed January 13, 2010, from the World Wide Web: http://www.deepdyve.com/lp/emerald-publishing/lessons-for-successful-bop-marketing-fromcaracas-slums-Gmy5mzWR0c

Jaiswal, A. K. (2008). CavinKare Private Limited: Serving Low Income Consumers. Asian Case Research Journal, [Online]. 12(1), 1-28. Accessed June 13, 2015, from the World Wide Web: https://ideas.repec.org/a/wsi/acrjxx/v12y2008i01p1-28.html

Jaiswal, A. K. (2007). Fortune at the Bottom of the Pyramid: An Alternate Perspective. Online. Accessed January 12, 2010, from the World Wide Web: http://www.iimahd.ernet.in/publications/data/200707-13Jaiswal.pdf

Jobber, D. \& Ellis-Chadwick, F. (2013). Principles and Practice of Marketing (7thed), New York: McGraw-Hill Higher Education.

Karnani, A. (2007). The Mirage of Marketing to the Bottom of the Pyramid: How the private sector can help alleviate poverty. Online. Accessed January 12, 2010, from the World Wide Web: http://wwwupdate.un.org/esa/coordination/Mirage.BOP. CMR.pdf

Keller, K. L. (2013). Strategic Brand Management: Building, Measuring and Managing Brand Equity (4thed), The United States of America: Pearson Education, Inc.

Kirchgeorg, M. \& Winn, M.I. (2006). Sustainable Marketing for the Poorest of the Poor. Business Strategy and the Environment, [Online]. 15, 171-184. Accessed May 18, 2012, from the World Wide Web: http://onlinelibrary.wiley.com/doi/ 10.1002/bse.523/abstract

Louw, A. I. (2008). Redefining BOP: In Pursuit of Sustainable Opportunity at the Base of the Economic Pyramid. MBA Thesis. Gordon Institute of Business Science, University of Pretoria.

Majumder, M. (2012). A Critical Approach in Understanding Bottom of the Pyramid Propositions. Journal of Management \& Public Policy, [Online]. 3(2), 18-25. Accessed June 13, 2015, from the World Wide Web: http://www.jmpp.in/archives/Mrinmoy\%20Majumder.pdf

McDaniel, C., Lamb, C. W. \& Hair, J. F. Jr. (2013). Introduction to Marketing (12 ${ }^{\text {th }}$ ed), Canada: South-Western, Cengage Learning.

Mendoza, R. U. (2008). Why do the poor pay more money? Exploring the poverty penalty concept. Journal of International Development, [Online]. 23, 1-28. Accessed May 18, 2012, from the World Wide Web: http://onlinelibrary.wiley.com/doi/ 10.1002/jid.1504/abstract

Nakata, C. \& Weidner, K. (2011). Enhancing New Product Adoption at the Base of the Pyramid: A Contextualized Model. Online. Accessed June 13, 2015, from the World Wide Web:http://onlinelibrary.wiley.com/doi/10.1111/j.1540-5885.2011.0087 6.x/pdf

Neuwirth, B. (2012). Marketing Channel Strategies in Rural Emerging Markets: Unlocking Business Potential. Online. Accessed July 21, 2012, from the World Wide Web: http://www.kellogg.northwestern.edu/.../...pdf

Nyanga, M. (2015). The nature of brand loyalty at the base of the pyramid. MBA Thesis. Gordon Institute of Business Science, University of Pretoria.

Oodith, P. D. \& Parumasur, S. B. (2017). Brand Consciousness of BOP Consumers in South Africa. Journal of Economics and Behavioural Studies, [Online]. 9(3), 82-100. Accessed October 17, 2017, from the World Wide Web: https://ifrnd.org/journal/ index.php/jebs/ article/view/1748/1446

Oodith, P. D. \& Parumasur, S. B. (2014). Being on Top of Your Game at the Bottom of the Pyramid. Corporate Ownership \& Control, [Online]. 11(3), 253-272. Accessed February 18, 2017, from the World Wide Web: http://www.virtusinterpress.org/IMG/pdf/10-22495_cocv11i3c2p4.pdf 
Oodith, P. D. \&Parumasur, S. B. (2013). Tapping into the Bottom of the Pyramid (BOP) Market in South Africa: Possible? And How? Corporate Ownership \& Control, [Online]. 11(1), 280-294. Accessed February 18, 2017, from the World Wide Web: http://www.virtusinterpress.org/IMG/pdf/1022495_cocv11i1c2art6.pdf

Pfeiffer, P. \& Massen, S. (2010). Serving the Low-Income Consumer: How to Tackle This Mostly Ignored Market. Online. Accessed December 21, 2010, from the World Wide Web: http://www.atkearney.com/index.php/Publications/serving-the-low-income-consumer.html

Pitta, D. A., Guesalaga, R. \& Marshall, P. (2008). The quest for the fortune at the bottom of the pyramid: potential and challenges. Journal of Consumer Marketing, [Online]. 25(7), 393-401. Accessed January 13, 2010, from the World Wide http://www.emeraldinsight.com/Insight/viewPDF.jsp?contentType=Article\&Filename=html/Output /Published/EmeraldFullTextArticle/Pdf/0770250704.pdf

Prahalad, C. K. (2012). Bottom of the Pyramid as a Source of Breakthrough Innovations. Journal of Product Innovation Management, [Online]. 29(1), 6-12. Accessed February 18, 2017, from the World Wide Web:http://onlinelibrary.wiley.com/doi/10.1111/j.1540-5885.2011.00872.x/pdf

Prahalad, C. K. (2005). The Fortune at the Bottom of the Pyramid: Eradicating Poverty through Profits, New Delhi: Pearson Education/Wharton School Publishing.

Prahalad, C. K. \& Hart, L. H. (2002). The Fortune at the Bottom of the Pyramid. Strategy+Business, [Online]. 26. Accessed December 2, 2010, from the World Wide Web: http://www.cs.berkeley.edu/ brewer/ict4b/Fortune-BoP.pdf

Rajagopal. (2009). Branding paradigm for the bottom of the pyramid markets. Measuring Business Excellence, [Online]. 13(4), 58-68. Accessed June 13, 2015, from the World Wide Web: http://www.emeraldinsight.com/doi/full/10.1108/13683040911 006792

Rijke, K. C., Diehl, J. C. \& Schoormans, J. P. L. (2009). Introducing solar products in rural Cambodia: A quest for the right marketing mix in base of pyramid markets. Online. Accessed June 13, 2015, from the World Wide Web: http://www.kcstrategic design.com/kamworks_files/Introducing\%20solar\%20products\%20in\%20rural\%20Cambodia.pdf

Sample Size Calculator. (2014). Online. Accessed February 4, 2014, from the World Wide Web: http://www.surveysystem.com/sscalc.htm

Schiffman, L. G. \& Wisenblit, J.L. (2015). Consumer Behavior (11 ${ }^{\text {th }}$ ed), England: Pearson Education Limited.

Sehrawet, M. \& Kundu, S.C. (2007). Buying behavior of rural and urban consumers in India: The impact of packaging. International Journal of Consumer Studies, [Online]. 31, 630-638. Accessed July 21, 2012, from the World Wide Web: http://onlinelibrary.wiley.com/doi/10.1111/j.14706431.2007.00629.x/full

Simanis, E. (2012). Reality Check at the Bottom of the Pyramid. Harvard Business Review. Online. Accessed October 17, 2017, from the World Wide Web: http://eriksimanis.com/wpcontent/uploads/2014/06/Simanis-Reality-Check-at-BOP-June-2012-HBR.pdf

Subrahmanyan, S. \& Gomez-Arias, J. T. (2008). Integrated approach to understanding consumer behavior at the bottom of pyramid. Journal of Consumer Marketing, [Online]. 25(7), 402-412. Accessed January 13, 2010, from the World Wide Web: http://www.emeraldinsight.com/Insight/viewPDF.jsp?contentType=Article\&Filename=html/Output /Published/EmeraldFullTextArticle/Pdf/0770250702.pdf

Tripathi, S. S. \& De, S. K. (2007). Innovation as a Tool of Building Competitive Advantage at the Bottom of the Pyramid. Online. Accessed January 12, 2010, from the World Wide Web: http://dspace.iimk.ac.in/bitstream/2259/374/1/171-179.pdf

Variawa, E. (2010). Buying behavior and decision-making criteria of Base of the Pyramid consumers: The influence of packaging on Fast Moving Consumer Goods customers' brand experience. MBA Thesis. Gordon Institute of Business Science, University of Pretoria.

World Economic Forum. (2009). The Next Billions: Unleashing Business Potential in Untapped Markets. Online. Accessed February 27, 2012, from the World Wide Web: https://members.weforum.org/pdf/BSSFP/ExecutiveSummaryUnleashingBusinesPotential.pdf

White, S. (2017). Influence of Packaging on Consumer Buying Behavior. Online. Accessed October 17, 2017, from the World Wide Web: https://www.labelvalue.com/documents/Influence-of-Packaging-onConsume-\%20Buying-Behavior.pdf 